\title{
原著 \\ 老年期高血圧者の皮膚色調 \\ Skin Color of the Japanese in High Blood \\ Pressure in Old Age
}

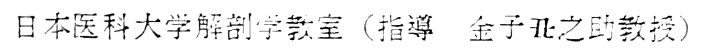

牛山喜美人

Ushiyama, Kimito

\section{緒言}

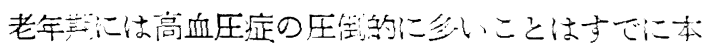
誌 20 巻 7 号に臨床報告として発表した。すなわち, それによると老年期汸てはその $60 \%$ 近くが高血圧 症である。しかしながら, 高血圧症については彷来赤 色高血圧症, 蒼白性高血圧症といらことがいわれ，彷 つてその人の示す皮覤色もあるいは赤く，あるいは荅 白であると記載されている。また，Volhardによれば 「赤色高血圧症とは終末血管に肊縮状態がなく，顔面 は亦く血中に脉管収䊒物滇のない高血圧症であり大体 本態泩鼠注高血圧症の大半，または Keith-Wagener の第一, 第二攻び第三型のはじめまでのもので, 蒼白

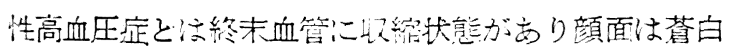
昧をるち血中に脉管收繀物蒉のある高血圧症で大体本 態生悪性高血圧症，すなわち Keith-Wagener の第四 型と腎炎性高血圧症の大半がこれに属する」と記載さ れている。しかし, 赤色高血圧症と薈白性高血圧症と の比率沉いての記載は全然見当らない。高血圧症と 称せられるものの中に赤色高血圧症と畣白性高血圧症 とはどんな比率をるつて存在するか。瑟は老年期高血 圧者の皮笜色声を謂査し，この間の奏態を把握せんと して，いささか值味ある成續を得たのでここに報告す る次第である。

\section{I. 被検者及び検䍒方法}

被検者は 61 才以上の水银血圧計を用いて，その最 高血压消か $151 \mathrm{~mm}$ 以上を呈方る者 352 名について 金子皮跑色計を用いて皮唐色調芯調査した。

\section{II. 検査成綪}

検査成績を記載するに先立つて，愁の使用した金子 皮蔳比色㖕について一言ふれることにする。すなわち
同比色計法W.Ostwald の色彩理諞にしたがつて製作

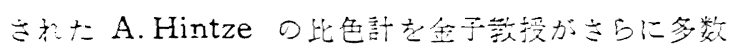
の色票と計测に便なる上う光沢を手際よく加味され，

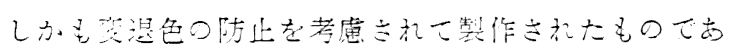
る。

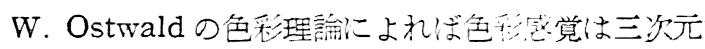
の色立体によつて表玩きれる。しかして，曋人が虫臂 色䛻について論じようとする坦台ここには多くの理 解しがたい問題があつた。たいい、この問題が三次元 の世界に生起する現象を論じなければならないという ことに起因する。彷来，吾人は色立体の中に方て占め

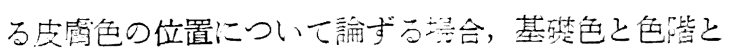
の 2 方面よりする態度をとつてきた, すなわち，この 三次元の問題を諭ずるにらたつて便宣上基睦色とい5 問題に限定した二次元の世界上，基筞色に応じた色調 分析という二资元の世界との二つの方面からこれを観

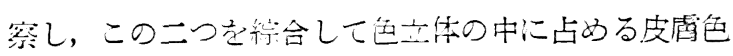
に結論をあた觉て来たのである。悡のこれから論じよ 5とする高血圧者の皮愿色謤について上上の方法諭的 立埸からするならば—二つ以上の皮有色を比較しよ うとする場合いずれが赤ないし蒼白であるかという問 題に対して——分がより江定的目子であるかとい5 と，そ机は基楚色である。すなわち，基礎色が高くな るといらことは赤䟽が增すということであり，基慗色 が低くなるということは赤味を成ずるということであ つて，とりもなおきず，鿓白昧を吅光ることになる。 もちろん基楚色の同じものの間に方仙て純色念有量と 白含有量とが法定䄪因子であることは，いうまでもな

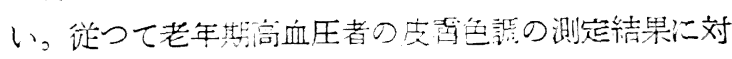

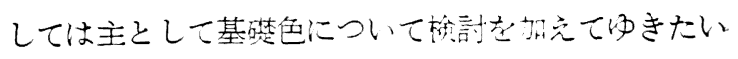


乙思5。しからば，何を以て赤色高血区症と苜白性高 血王症との限界とするか。私は老年期保常者, すなわ ちその最高血圧偡が101〜150mm の間沈るるのの平 均基整色を以て一応えの限界之定め，これより低いも のは荅白性高血圧症の中沪，これより高いものは赤色 高血症の中に入れることとする。この立場をとると き, 荅白性高血圧症の中にも, 赤色高血圧症の中にも 共滥常者の示寸皮愿色をもつもののあることは当然 である。しかし，たと元こ狆らのものを含めるとして もな妨蒼白性高血圧症と赤色高血压症とが高血正症の 中に於て占める注㼁の分布状態ないし比率を知る上に は何等の䛊街もないとみて差しつかえないと考える。

老年期篇にのべた如く老年期倠常者，すなわちその 最淌血圧值が 101 150 mm の間汇㐫るものの上腕内 側の平均基礎色は $33.67 ％ 3.69$ で老年期高血圧者の 上腕内側の基礎色についてこれを限界としてそれより 高いものと低いものとの 2 群を声査して見ると表 1 の 如くなる，

すなわち，高血王者全体としてみた場合その分布状態 ないし比率の性による差異は著明ではなく荅白性高血 压症は約 2.5 倍多い。

また血圧が高くなると悪性高血圧症の频度が多くな り彷つて荅白性高血圧症の頻度が高くなるだろうと予 想されるのであるが，事実は最高血圧值 $161 \mathrm{~mm}$ 以上 のものの間に於てさしたる変化を認めることは而来な い。151〜160 mm の所では闭者の間に男女いずれる 僅少の差を認めるのみである。

次に色階についてみると男女ともに上腕内則に於て 一番出現頻度の多い基礎色は 3.5 である。よつて, 基 碟色 3.5 亿属寸る高血圧者の血圧別皮膚色調分析を行 つてみると表 2 の如くなる。

純色含有量 血殴が高くなるにつれて男子では各血 圧下それぞれ 24.1，24.3，24.8，24.9，24.6，25.7， $25.4,24.3,24.1$ と純色念有量は变化している, 女 子ではそれぞれ 24.8，25.0，24.6，24.7，24.4，24.1， 23.4, 24.6, 25.4, 25.2 となつている。

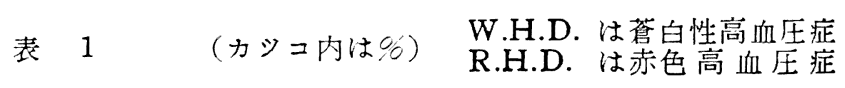

\begin{tabular}{|c|c|c|c|c|c|c|c|c|c|c|c|c|}
\hline 性 & $\begin{array}{l}\text { 血压 } \mathrm{mm} \\
\text { 高血压分類 }\end{array}$ & $\begin{array}{r}151 \sim \\
160\end{array}$ & $\begin{array}{l}161 \sim \\
170\end{array}$ & $\begin{array}{r}171 \sim \\
180\end{array}$ & $\begin{array}{r}181 \sim 0 \\
190\end{array}$ & $\begin{array}{r}191 \sim \\
200\end{array}$ & $\begin{array}{r}201 \sim \\
210\end{array}$ & $\begin{array}{r}211 \sim \\
220\end{array}$ & $\begin{array}{r}221 \sim \\
230\end{array}$ & $\begin{array}{r}231 \sim \\
240\end{array}$ & $\begin{array}{l}241 \\
\text { 以 } 上\end{array}$ & $\begin{array}{l}\text { 計 } \\
(\%)\end{array}$ \\
\hline \multirow{2}{*}{$\delta$} & W. H. D. & $\begin{array}{c}15 \\
(57.6)\end{array}$ & $\begin{array}{c}21 \\
(77.7)\end{array}$ & $\begin{array}{c}22 \\
(73.3)\end{array}$ & $\begin{array}{c}11 \\
(91.6)\end{array}$ & $\begin{array}{c}5 \\
(55.5)\end{array}$ & $\begin{array}{c}6 \\
(100)\end{array}$ & $\begin{array}{l}1 \\
(20)\end{array}$ & $\begin{array}{c}5 \\
(83.3)\end{array}$ & 0 & $\begin{array}{c}2 \\
(100)\end{array}$ & $\begin{array}{c}88 \\
(71.5)\end{array}$ \\
\hline & R. H. D. & $\begin{array}{c}11 \\
(42.4)\end{array}$ & $\begin{array}{c}6 \\
(22.3)\end{array}$ & $\begin{array}{c}8 \\
(26.7)\end{array}$ & $\begin{array}{c}1 \\
(8.4)\end{array}$ & $\begin{array}{c}4 \\
(44.5)\end{array}$ & 0 & $\begin{array}{c}4 \\
(80)\end{array}$ & $\begin{array}{c}1 \\
(16.7)\end{array}$ & 0 & 0 & $\begin{array}{c}35 \\
(28.5)\end{array}$ \\
\hline \multirow{2}{*}{ P } & W. H. D. & $\begin{array}{c}38 \\
(56.7)\end{array}$ & $\begin{array}{c}49 \\
(80.3)\end{array}$ & $\begin{array}{c}45 \\
(70.3)\end{array}$ & $\begin{array}{c}32 \\
(84.2)\end{array}$ & $\begin{array}{c}32 \\
(84.2)\end{array}$ & $\begin{array}{l}20 \\
(80)\end{array}$ & $\begin{array}{c}18 \\
(69.2)\end{array}$ & $\begin{array}{c}9 \\
(81.8)\end{array}$ & $\begin{array}{c}5 \\
(71.4)\end{array}$ & $\begin{array}{c}7 \\
(70)\end{array}$ & $\begin{array}{r}257 \\
(73.2)\end{array}$ \\
\hline & R. H. D. & $\begin{array}{c}29 \\
(43.3)\end{array}$ & $\begin{array}{c}12 \\
(19.7)\end{array}$ & $\begin{array}{c}19 \\
(29.7\end{array}$ & $\begin{array}{c}6 \\
(15.8)\end{array}$ & $\begin{array}{c}6 \\
(15.8)\end{array}$ & $\begin{array}{l}5 \\
(20)\end{array}$ & $\begin{array}{c}8 \\
(30.8)\end{array}$ & $\begin{array}{c}2 \\
(18.2)\end{array}$ & $\begin{array}{c}2 \\
(28.6)\end{array}$ & $\begin{array}{c}3 \\
(30)\end{array}$ & $\begin{array}{r}94 \\
(26.8)\end{array}$ \\
\hline
\end{tabular}

表 2

\begin{tabular}{|c|c|c|c|c|c|c|c|c|c|c|c|c|}
\hline 基礎色 & & 色調分析 & $151 \sim 20$ & $\begin{array}{r}161 \sim \\
170\end{array}$ & $\begin{array}{r}171 \sim \widetilde{\sim} \\
\quad 180\end{array}$ & ${ }_{190}^{181}$ & $\begin{array}{r}191 \sim \\
200\end{array}$ & $\begin{array}{r}201 \sim \\
210\end{array}$ & $\begin{array}{r}211 \sim \\
220\end{array}$ & $\begin{array}{r}221 \sim \\
230\end{array}$ & $\begin{array}{r}231 \sim \\
240\end{array}$ & $\underset{\text { 以上 }}{241 \mathrm{~mm}}$ \\
\hline \multirow{6}{*}{3.5} & \multirow{3}{*}{5} & 純色实有量 & 24.1 & 24.3 & 24.8 & 24.9 & 24.6 & 25.7 & 25.4 & 24.3 & & 24.1 \\
\hline & & 白令有量 & 20.9 & 20.3 & 19.8 & 20.0 & 18.9 & 19.3 & 24.8 & 18.3 & & 24.1 \\
\hline & & 黒宫有量 & 55 & 55.4 & 55.4 & 55.1 & 56.5 & 55.0 & 49.8 & 57.4 & & 55.9 \\
\hline & \multirow{3}{*}{7} & 純色宫有量 & 24.8 & 25.0 & 24.6 & 24.7 & 24.4 & 24.1 & 23.4 & 24.6 & 25.4 & 25.2 \\
\hline & & 白含有量 & 23.7 & 22.8 & 21.6 & 20.8 & 21.3 & 20.1 & 22.8 & 23.8 & 24.8 & 20.9 \\
\hline & & 黑合有量 & 51.5 & 52.2 & 53.8 & 54.5 & 54.3 & 55.8 & 53.8 & 51.6 & 49.8 & 53.9 \\
\hline
\end{tabular}

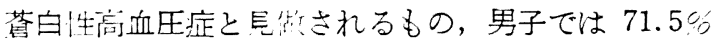
女子では $73.2 \%$ で志り赤色高血圧症と見做されるも

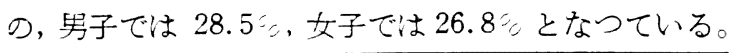

本分钼法は単に見かけ上，色謂のみからなしたもの で，臨床的機能梳査を行つたものでない。
白含有量 白含有量は血圧が高くなるに良つて男子 では各血王下それぞれ 20.9，20.3，19.8，20.0，18.9， 19.3，24.8，18.3，20 となり，女子ではこれぞれ $23.7,22.8,21.6,20.8,21.3,20.1,22.8,23.8$, $24.8,20.9$ となつている。 
黑含有量 黒含有量は男子では各血圧下それぞれ $55,55.4,55.4,55.1,56.5,55.0,49.8,57.4$, 55.9，女子ではそれぞれ 51.5，52.2, 53.8, 54.5, 54.3， $55.8 ， 53.8 ， 51.6 ， 49.8 ， 53.9$ と血圧の高くなるに つれて变化している。

\section{総括及び結論}

老年期高血圧者 352 名沉ついて金子皮虞比色計を用 いて外界の影智を受けることの最もすくない上腕内側 の皮虐色䛯を測定して, 結論的に次の傾向を知り得た (このさい高血圧者の臨床的機能的梌楂はなされてい ない単なる外見上の分類である)。

1）高血圧者の平均基礎色は煡常者のそれよりも低 いか，その理由は蒼白性高血圧症と赤色性高血圧症々 が存在することによる。

2）基碟色によつて分類した荅白性高血圧症と赤色 高血圧症との比率は, 前者が後者の約 2.5 倍に相当 し，性によつて著明な变化を認めることはできない。

3）基碟色によつて分類した荅白性高血圧症と赤色 高血压症との比率は，血圧の高さによつて変化しな い。但し最高血厌值 151 160 mm の所で汢仙者の差 は僅少である。

4）純色含有量 : 同一基楚色つなかで男子では血圧 が高くなると增加し, 最高血圧值 201〜210 mm の所 を頂点としそれ以後はすくなくなる。女子では特別な 傾向が見られないが，201〜210 mm の所浅い行を 作つている。
(581) $-9-$

5）白含有量：同じ基礎色のなかでは荲子では大体 の傾向として血圧が高くなると減少し，201～210 mm を限度としてそれ以後は再び増加する。女子では血圧 が高くなるにしたがつて減少し，201〜210 mm を限度 としそれ以後は再ご増加している。

6）黒含有量：男子では特与な变化がない，女子で は血压が高くなると增加し，201２10 mmを頂点とし それ以後は澧減している。

7）純色，白，黑含有量の著明な变化が最高血王值 201〜210 mm の所で生起している理由は解らない。 今後の研究に矣ちたい。

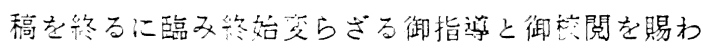

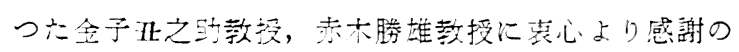
意を表する。

\section{交献}

1) 小柳美三: 日本眼科学全程誌，4之，1P

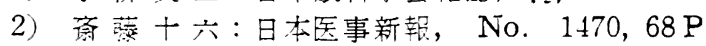
(昭. 27)

3) 中沢房吉: 臨床, 8 (䧂. 27)

4) 大島研三：最新の臨床，第6 集 (昭. 27)

5) 楠井賢浩：治療，1P（昭. 27)

6）大沢章通：日医大䛱，18，3号,60 P (昭. 26)

7) 金子丑之助：解剖学椎誌，8，365 P (昭.10)

8）佐久間正美：日医大点，18，8号，8P(昭. 26)

9) Volhard: Nierenerkrankungen u. Hochdruck (1949), S. 299 